\title{
Sporadic colorectal cancer in adolescents and young adults: a scoping review of a growing healthcare concern
}

\author{
Natasha Christodoulides ${ }^{1,2}$ (1) Mariam Lami ${ }^{1} \cdot$ George Malietzis $^{1,2,3} \cdot$ Shahnawaz Rasheed $^{3} \cdot$ Paris Tekkis $^{1,2,3}$. \\ Christos Kontovounisios ${ }^{1,2,3}$
}

Accepted: 3 June 2020 / Published online: 15 June 2020

(C) The Author(s) 2020

\begin{abstract}
Purpose Sporadic colorectal cancer (CRC) amongst adolescents and young adults (AYA) is increasing in incidence. The reasons for this trend are not well understood. Current guidelines do not specifically address this patient cohort. A scoping review was performed to summarise the range of available evidence and identify key areas that need to be addressed in current guidelines. Methods A systematic literature search was conducted adhering to the PRISMA statement. All potentially eligible studies were screened, and data extraction was performed by two reviewers independently. The studies were then divided into 5 broad subgroups: (1) risk factors, (2) screening, (3) clinicopathological and molecular features, (4) presentation and (5) management. Descriptive statistics were used for data analysis.

Results A total of 17 studies were included from 2010 to 2019. Overall, young adults with CRC tend to present with non-specific symptoms. The majority of these patients have a delayed diagnosis and more advanced disease at presentation, with a rise in prevalence of distal colon and rectal cancers. AYAs tend to have poorly differentiated tumours and are managed more aggressively. Overall 5-year survival varies between studies.

Conclusion This is, to our knowledge, the first scoping review presenting the range of available evidence on CRC in AYAs. Although the rise in incidence is recognised by specialist bodies, recommendations are limited by the sparsity of available data. We seek to highlight the need for further research, define the role of earlier screening and raise awareness to promote thorough assessment of young patients.
\end{abstract}

Keywords Colorectal cancer $\cdot$ Sporadic $\cdot$ Young adults $\cdot$ Adolescents

\section{Introduction}

Colorectal cancer (CRC) is the 2nd most common cause of cancer death in the UK and the 3rd most common cancer worldwide [1,2]. Although CRC still remains a disease of older adults, incidence has been increasing in recent years amongst adolescents and young adults (AYAs) aged $\leq$

Natasha Christodoulides and Mariam Lami contributed equally to this work.

Natasha Christodoulides

natasha.christodoulides19@imperial.ac.uk

1 Chelsea and Westminster Hospital, London, UK

2 Department of Surgery and Cancer, Imperial College, South Kensington Campus, London SW7 2AZ, UK

3 Royal Marsden Hospital, London, UK
49 years old [3, 4]. Although CRC linked to familial syndromes is more common in AYAs, the majority of cases in this age group are sporadic [5]. This patient group tends to have a delayed diagnosis and more advanced disease at presentation $[3,6,7]$.

Recent research has identified the growing threat of CRC in AYAs through assessment of epidemiology, risk factors, molecular features and prognosis. To date, results have been insufficient to achieve an effective change in guidelines [8]. A scoping review was performed to summarise the range of available evidence and identify key areas that need to be addressed in current guidelines. Our primary objective is to present an overview of the available evidence pertaining to risk factors, screening, pathological and molecular features, presentation and management of CRC in AYAs. Our secondary objective is to review current guidelines addressing this patient cohort and make suggestions that can be incorporated into these guidelines. 


\section{Methods}

\section{Search strategy}

We followed the scoping review framework proposed by Arksey and O'Malley, addressing all six stages of the methodological framework [9]. A comprehensive literature search was performed in consultation with a trained librarian, to identify all publications discussing the aetiology, screening, molecular features, presentation and management of colorectal cancer in AYAs. We reviewed the literature using MEDLINE, PubMed and EMBASE databases, in accordance with the PRISMA guidelines [10]. Keywords used in the search were: "colorectal cancer", "under 50", "colorectal neoplasms", "pathology", "young adult", "United Kingdom", "aggression", "risk factor", "screening", "chemotherapy", "diagnosis", "surgery", "epidemiology", "management" and "practice guideline". These keywords were selected to identify the maximum number of articles relevant to the chosen topic. All searches were performed in December 2019. No study limitations or time restrictions were set.

\section{Eligibility criteria}

Articles were included in this scoping review if they met the following broad eligibility criteria: (1) published in English;
(2) published in full-text format; (3) focussed on sporadic CRC in AYAs $\leq 49$ years old; (4) discussed one of the following areas: risk factors, screening, molecular and pathological features, presentation and management; (5) level I to V evidence; (6) excluded articles discussing hereditary CRC syndromes only; (7) excluded other cancer types.

\section{Article selection and data extraction}

The abstracts identified in the search were reviewed independently by two reviewers. Any disagreement between reviewers about whether a paper should be included resulted in inclusion at this stage in the process. The full-text articles were then reviewed by two reviewers and a final consensus was reached.

The studies were then divided into 5 broad subgroups: (1) risk factors; (2) screening; (3) clinicopathological and molecular features; (4) presentation and (5) management. Data relating to study characteristics (location of research, year, journal of publication, study design) was extracted, as well as data relating to one or more of the outcome themes (risk factors, recommendations for screening, unique pathological features, presentation and management).
Fig. 1 PRISMA 2009 flow diagram [10]

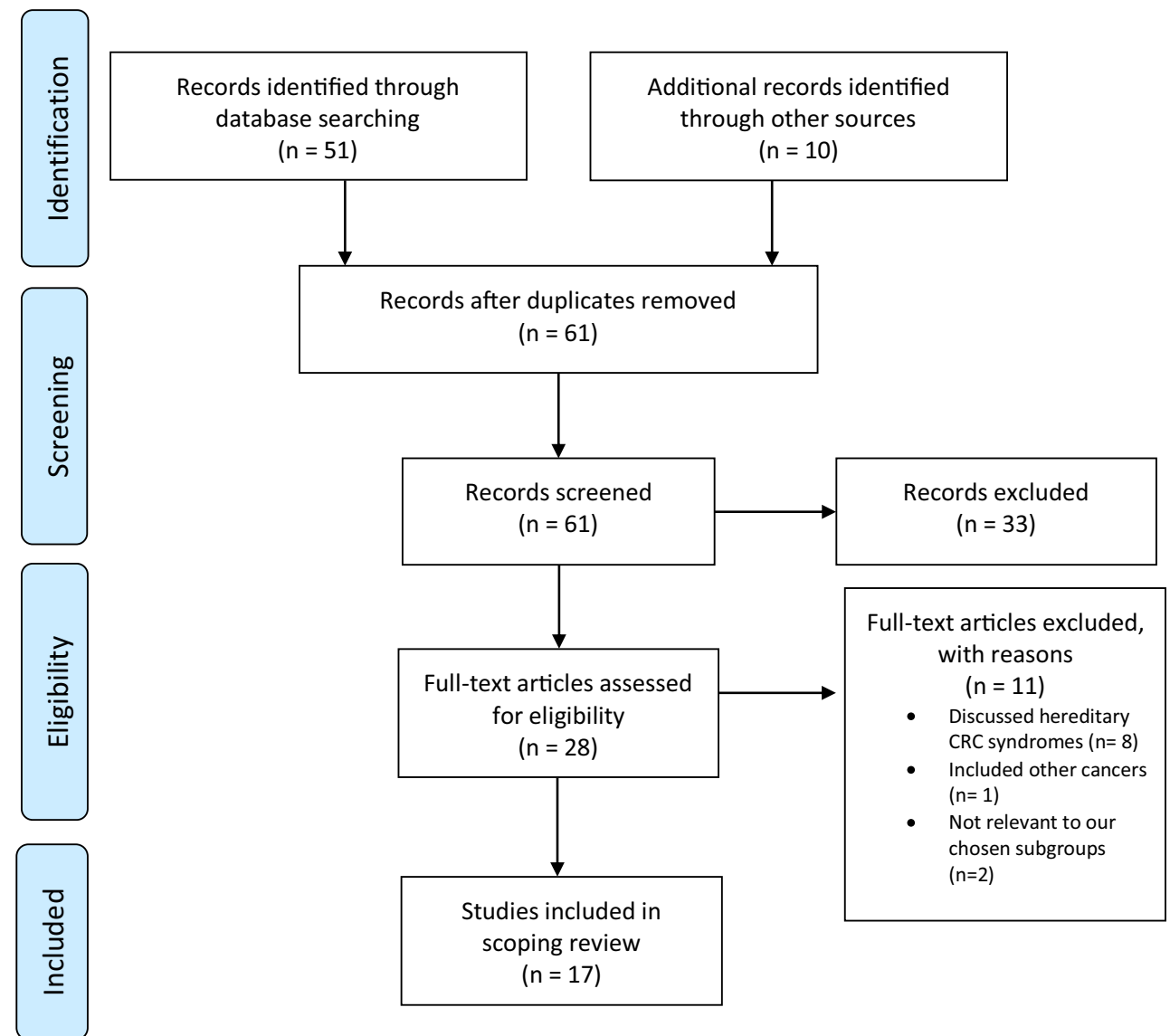




\section{Data analysis}

The data was summarised using descriptive statistics. Where applicable, data was analysed and presented as a proportion of the total. Categorical variables are reported as percentages. Inferential statistical testing was not performed. Level of evidence was assessed by assigning an Oxford Centre for Evidence Based Medicine (OCEMB) score to each paper [11].

\section{Results}

In total, 61 articles were reviewed, of which 44 were excluded due to the following reasons: the cut-off age for the young patient cohort was $\geq 50$ years old, looked at other cancers, included hereditary syndromes only, were not relevant to our chosen subgroups (Fig. 1).

Our scoping review identified 17 papers from 2010 to 2019. The majority of included studies were from North America (52.9\%), with some representation from Europe (23.5\%) and Asia (23.5\%). No relevant studies were published before 2010 . A total of $88.2 \%$ of included studies were assigned an OCEMB score of 2 (Table 1). A minority of studies included patients in the $\leq 20$ or $<50$ age groups, whilst $82.4 \%$ of studies discussed patients in the $\leq 30$ group and $58.8 \%$ included patients who were $\leq 40$ years of age. A total of $94.1 \%$ of relevant studies discussed CRC, whilst one paper analysed and discussed trends in rectal cancer only. Study design and characteristics of the included studies are illustrated in Table 1.

\section{Risk factors}

We identified seven studies which analysed and discussed risk factors for young-onset colorectal cancer. Recognised risk factors for CRC such as family history, lifestyle factors, metabolic syndrome and inflammatory bowel disease (IBD) were reflected in our results (Table 2).

As highlighted by Weinberg et al., most young patients with CRC have sporadic disease, and only a small proportion of patients with familial CRC have an identifiable hereditary syndrome [5, 19]. Family history is recognised as a potential risk factor in $42.9 \%(n=3)$ of the included studies. Al-Barrak and Gill, however, go one step further to suggest that family history of a first degree relative is less likely to be a factor in this patient population as, by virtue of age, family history is vigorously pursued in these patients [16]. In their retrospective cohort study, Tawadros et al. identified race "other than black or white" as an independent risk factor for rectal cancer in patients $<40$ years of age [18]. Rosato et al. report no significant association between obesity and a sedentary lifestyle to CRC in subjects $\leq 45$ years, although this is likely attributed to the small sample size [17].
Table 1 Study design and characteristics of the included studies

\begin{tabular}{|c|c|}
\hline Characteristic & Frequency $\mathrm{N}(\%) \mathrm{N}=17$ \\
\hline \multicolumn{2}{|l|}{ Location of Research ${ }^{\mathrm{a}}$ : } \\
\hline USA & $8(47.1)$ \\
\hline Taiwan & $2(11.8)$ \\
\hline Germany & $1(5.9)$ \\
\hline Korea & $1(5.9)$ \\
\hline The Netherlands & $1(5.9)$ \\
\hline Canada & $1(5.9)$ \\
\hline Italy & $1(5.9)$ \\
\hline China & $1(5.9)$ \\
\hline Czech Republic & $1(5.9)$ \\
\hline Lebanon & $1(5.9)$ \\
\hline \multicolumn{2}{|l|}{ Year of publication: } \\
\hline 2010-2014 & $7(41.2)$ \\
\hline 2015-2019 & $10(58.8)$ \\
\hline \multicolumn{2}{|l|}{ Study design: } \\
\hline Retrospective cohort study & $13(76.5)$ \\
\hline Prospective comparative study & $2(11.8)$ \\
\hline Case series & $1(5.9)$ \\
\hline Letter & $1(5.9)$ \\
\hline \multicolumn{2}{|l|}{ OCEBM Score: } \\
\hline Level 2 & $15(88.2)$ \\
\hline Level 4 & $1(5.9)$ \\
\hline Level 5 & $1(5.9)$ \\
\hline \multicolumn{2}{|l|}{ Age of AYAs (years) ${ }^{\mathrm{b}}$ : } \\
\hline$\leq 20$ & $4(23.5)$ \\
\hline$\leq 30$ & $14(82.4)$ \\
\hline$\leq 40$ & $10(58.8)$ \\
\hline$<50$ & $2(11.8)$ \\
\hline \multicolumn{2}{|l|}{ Site: } \\
\hline Colorectal & $16(94.1)$ \\
\hline Rectal cancer & $1(5.9)$ \\
\hline \multicolumn{2}{|l|}{ Outcome themes ${ }^{\mathrm{c}}$ : } \\
\hline Risk factors & $7(41.2)$ \\
\hline Screening & $6(35.3)$ \\
\hline Clinicopathological and molecular features & $4(23.5)$ \\
\hline Presentation & $3(17.6)$ \\
\hline Management & $6(35.3)$ \\
\hline
\end{tabular}

${ }^{\mathrm{a}} 1$ study was conducted in multiple locations

${ }^{\mathrm{b}}$ Overlap between studies; 1 study not included as not applicable

${ }^{\mathrm{c}}$ Some studies applicable to multiple outcome themes

Al-Barrak and Gill evaluated the role of inflammatory conditions in AYA CRC [16]. In this study, IBD was documented as a risk factor in $15 \%$ of patients $\leq 30$ years old. These patients were more likely to present with metastatic disease (29\% compared to $9 \%$ with localised disease) [16]. This is especially significant as IBD-associated dysplastic lesions have been shown to be more genomically unstable, perhaps 
Table 2 Risk factors identified in young-onset colorectal cancers

\begin{tabular}{|c|c|c|c|c|c|c|c|c|c|c|c|}
\hline Authors & Country & Study design & $\begin{array}{l}\text { Family } \\
\text { history }\end{array}$ & $\begin{array}{l}\text { Male } \\
\text { gender }\end{array}$ & Race & $\begin{array}{l}\text { Obesity/ } \\
\text { sedentary } \\
\text { lifestyle }\end{array}$ & $\begin{array}{l}\text { Unhealthy } \\
\text { dietary } \\
\text { pattern/ } \\
\text { processed } \\
\text { meat }\end{array}$ & Smoking & Alcohol & $\begin{array}{l}\text { Diabetes } \\
\text { mellitus }\end{array}$ & $\begin{array}{l}\text { Microbiota/ } \\
\text { IBD }\end{array}$ \\
\hline $\begin{array}{l}\text { Siegel et al. } \\
\text { [12] }\end{array}$ & USA & $\begin{array}{l}\text { Retrospective } \\
\text { cohort study }\end{array}$ & - & - & - & Yes & Yes & - & - & - & - \\
\hline $\begin{array}{c}\text { Kwak et al. } \\
\text { [13] }\end{array}$ & Korea & Prospective study & - & - & - & - & - & Yes & Yes & - & - \\
\hline $\begin{array}{l}\text { Chen et al. } \\
\text { [14] }\end{array}$ & Taiwan & $\begin{array}{l}\text { Retrospective } \\
\text { cohort study }\end{array}$ & Yes & Yes & - & Yes & - & - & - & Yes & - \\
\hline $\begin{array}{c}\text { Kim et al. } \\
\text { [15] }\end{array}$ & Korea & $\begin{array}{l}\text { Cross-sectional } \\
\text { analysis }\end{array}$ & - & Yes & - & Yes & Yes & Yes & Yes & Yes & - \\
\hline $\begin{array}{l}\text { Al-Barrak } \\
\text { and Gill } \\
{[16]}\end{array}$ & Canada & $\begin{array}{l}\text { Retrospective } \\
\text { cohort study }\end{array}$ & Yes & - & - & - & - & - & - & - & Yes \\
\hline $\begin{array}{l}\text { Rosato et al. } \\
\text { [17] }\end{array}$ & Italy & $\begin{array}{l}\text { Retrospective } \\
\text { cohort study }\end{array}$ & Yes & - & - & $\begin{array}{l}\text { No } \\
\quad \text { association }\end{array}$ & Yes & - & Yes & $\begin{array}{l}\text { No } \\
\quad \text { association }\end{array}$ & - \\
\hline $\begin{array}{l}\text { Tawadros } \\
\text { et al. [18] }\end{array}$ & USA & $\begin{array}{l}\text { Retrospective } \\
\text { cohort study }\end{array}$ & - & - & $\mathrm{Yes}^{\mathrm{a}}$ & - & - & - & - & - & - \\
\hline
\end{tabular}

${ }^{a}$ Race "other than black or white" identified as an independent risk factor

reflecting a faster progression towards cancer and greater metastatic potential $[16,20]$.

\section{Screening}

All 6 studies (100\%) included in this subgroup recommended the consideration of earlier screening (Table 3). Following a retrospective analysis of incidence statistics from the Surveillance, Epidemiology and End Results (SEER) database, Davis et al. recommend colonoscopic age-based screening for average risk patients from 40 years [4]. Here, CRC locations were compared to determine the most suitable screening method [4]. Schellerer et al., however, recommend rigid rectoscopy from the age of 40, with colonoscopy or sigmoidoscopy with FOB testing in selected patients only [21]. This is based on evidence that two-thirds of young patients present with rectal tumours [21]. They suggest that lowering the age of screening from 50 to 40 would raise costs whilst identifying only $10 \%$ of CRC patients [21].

In their retrospective cohort study, Peterse et al. describe the use of an adjusted Microsimulation Screening AnalysisColon (MISCAN-Colon) model to make screening recommendations based on life-years gained [22]. They conclude that initiation of screening at age 45 offers a favourable balance between screening benefits and burden [22]. They advise either colonoscopy every 10 years, faecal immunochemical

Table 3 Colorectal cancer screening

\begin{tabular}{|c|c|c|c|c|}
\hline Authors & Country & Study design & $\begin{array}{l}\text { Earlier screening } \\
\text { recommended }\end{array}$ & $\begin{array}{l}\text { Screening modality } \\
\text { recommended }\end{array}$ \\
\hline Davis et al. [4] & USA & Retrospective cohort study & Yes & $\begin{array}{l}\text { Colonoscopic screening } \\
\text { from } 40 \text { years }\end{array}$ \\
\hline Schellerer et al. [21] & Germany & Letter & Yes & $\begin{array}{l}\text { Rigid rectoscopy from } \\
40 \text { years }\end{array}$ \\
\hline Siegel et al. [12] & USA & Retrospective cohort study & Yes & - \\
\hline Singh et al. [3] & USA & Retrospective cohort study & Yes & - \\
\hline Peterse et al. [22] & The Netherlands/USA & Retrospective cohort study & Yes & $\begin{array}{l}\text { Colonoscopy every } \\
10 \text { years or FIT yearly or } \\
\text { flexible sigmoidoscopy } \\
\text { or CTC every } 5 \text { years } \\
\text { from } 45 \text { to } 75 \text { years }\end{array}$ \\
\hline Chang et al. [23] & USA & Retrospective cohort study & Yes & - \\
\hline
\end{tabular}

FIT faecal immunochemical test, CTC CT-colonography 
testing (FIT) every year or flexible sigmoidoscopy or CTcolonography every 5 years from 45 to 75 years of age [22].

\section{Clinicopathologic and molecular characteristics}

We identified 4 papers discussing clinicopathologic and molecular characteristics of sporadic CRC in patients $\leq 49$ years old. The age range of AYAs across studies was 14 to 45 years, with the percentage incidence approximately equal between genders (Table 4).

The most common site at diagnosis in the younger age group was the left colon and rectum $[6,23]$ (Table 4). On review of tumour staging and prognosis, we identified that younger patients were more likely to present with stage III or IV CRC. Survival figures between the younger and older patient cohorts within each study were approximately equal. Survival varied between studies (Table 4).

Overall, on comparison of pathological features, younger patients were more likely to have poorly differentiated tumours, present with metastases and have cancers that are mucinous or signet-ring cell in histology (Table 5). Chang et al., however, identified no difference between the two groups when comparing mucinous histology [23]. Kothari et al. performed targeted exome sequencing to investigate whether genetic differences exist between age cohorts and found that mutations in the FBXW7 gene were more common in the younger group, as were mutations in the POLE proofreading domain [24].

\section{Presentation}

We identified 3 papers that analysed and reported data on the presenting symptoms of CRC in AYAs (Table 6). Rectal bleeding was the commonest symptom across all disease stages. Patients with stage IV disease commonly presented with rectal bleeding and abdominal pain [16]. Other common symptoms included change in bowel habit and tenesmus (Table 6). Reported symptoms are often non-specific and in the absence of risk factors can lead to delayed diagnosis $[6,7$, 16]. Kocian et al. report that $78.9 \%$ of patients under the age of 40 presented with advanced-stage disease with resultant poor prognosis [7].

\section{Management}

Six studies analysed the management of CRCs in AYAs (Table 7). Across these studies, the majority of cancers were located in the distal colon and rectum (Table 7). As discussed previously, young patients were more likely to present with advanced disease (TNM stage III or IV). Despite the advanced stage at presentation, the majority of young patients underwent surgical resection and chemotherapy. Compared to older CRC patients, aggressive treatment with multiagent

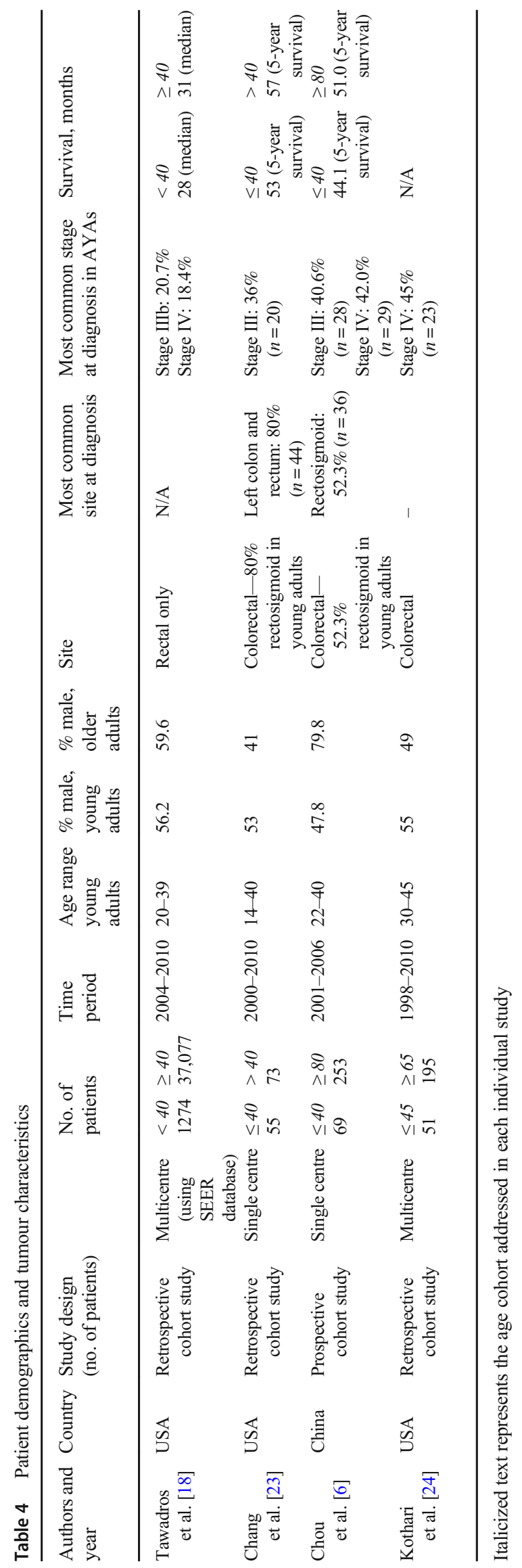


Table 5 Analysis of pathological features

\begin{tabular}{|c|c|c|c|c|c|c|c|c|}
\hline \multirow[t]{2}{*}{ Authors } & \multicolumn{2}{|l|}{ Mucinous } & \multicolumn{2}{|c|}{ Signet-ring cell } & \multicolumn{2}{|c|}{ Poorly differentiated } & \multicolumn{2}{|c|}{ Metastasis } \\
\hline & AYA $\%$ & Control \% & AYA $\%$ & Control \% & AYA \% & Control \% & AYA $\%$ & Control \% \\
\hline Chou et al. [6] & $\begin{array}{r}14.5 \text { (mucinous or } \\
\text { signet-ring cell) }\end{array}$ & $\begin{array}{l}6.3 \text { (mucinous or } \\
\text { signet-ring cell) }\end{array}$ & - & - & 26.1 & 16.3 & 42.0 & 13.4 \\
\hline Chang et al. [23] & 24 & 85 & 87 & 99 & 22.2 & 14.7 & 27 & 14 \\
\hline Tawadros et al. [18] & 9.20 & 5.6 & 3 & 0.87 & 21.1 & 13.3 & 18.4 & 12.3 \\
\hline
\end{tabular}

chemotherapy regimens and biologics were more likely to be used in AYAs overall, including at earlier stages of disease [7, 26]. No significant difference however is reported in overall 5year survival between the older and younger patient cohorts $[6,7,26]$. Zhao et al. report significantly lower 5-year survival in the younger group with stage III disease [27].

\section{Discussion}

Seventeen studies across 10 countries evaluating risk factors, presentation, screening, management and clinicopathological and molecular features of sporadic young-onset colorectal cancer were included. Whilst other narrative reviews have been published $[8,28]$, this is to our knowledge the first scoping review presenting the broad range of available evidence.

Although the absolute incidence of colon and rectal cancers in young adults $\leq 49$ years of age is low overall, a change in epidemiology with a significant rise in incidence has been clearly documented in the literature [3, 5, 29]. A recently published systematic review by Saad El Din et al., assessing population trends of CRC in AYAs, highlights the increasing risk of $\mathrm{CRC}$ in this patient cohort, largely driven by rectal cancers [29]. Current guidelines do not reflect this epidemiological shift, which poses new challenges in screening, diagnosis and management.

The National Comprehensive Cancer Network (NCCN) guidelines recognise the rise in incidence of sporadic $\mathrm{CRC}$ in the young [30]. It is estimated that the incidence rates for colon and rectal cancers will increase by $90 \%$ and $124.2 \%$ respectively for patients 20-34 years old by 2030 [30]. Moreover, if it becomes broadly accepted that CRC in the young is a unique disease entity, there would be a need to develop targeted treatment strategies [30]. A summary of the relevant information available in guidelines from national and international specialist bodies is highlighted in Table 8 .

All studies included under the outcome theme of screening recommend that earlier screening should be instigated (Table 3). Currently, CRC screening in the UK in patients with no known risk factors begins at the age of 60 with a faecal occult blood test (FOBT) [32]. Screening occurs every 2 years up to the age of 74. In some areas, a one-off colonoscopy is offered at the age of 55 [32]. The American Cancer Society (ACS) has updated its guideline on colorectal cancer screening and now recommends screening at 45 years of age for patients at average risk [34]. In a UK population-based analysis, Yong et al. demonstrate the rising incidence of CRC in AYAs [35]. While a cost-effectiveness analysis needs to be carried out before any changes can be made to UK National Bowel Cancer screening guidelines, based on our scoping review, we propose screening with a flexible sigmoidoscopy at the age of 40 in patients at average risk. To do this successfully, it is essential to raise awareness, particularly in primary care. We propose developing questionnaires which incorporate known risk factors, to be used opportunistically in the community to identify patients $\geq 40$ years old who are at average risk. To successfully define "average risk" in the UK, further population-based studies are required. With recall

Table 6 Presenting symptoms

\begin{tabular}{|c|c|c|c|c|c|c|c|}
\hline Authors & Country & Study design & No. of patients & Bleeding $n(\%)$ & $\begin{array}{l}\text { Abdominal pain } \\
n(\%)\end{array}$ & $\begin{array}{l}\text { Change in bowel } \\
\text { habit } n(\%)\end{array}$ & Tenesmus $n(\%)$ \\
\hline Kocian et al. [7] & Czech Republic & $\begin{array}{l}\text { Retrospective } \\
\text { cohort study }\end{array}$ & 38 & $18(47.4)$ & $7(18.4)$ & $8(21.0)$ & $4(10.5)$ \\
\hline \multirow[t]{2}{*}{ Al-Barrak et al. [16] } & \multirow[t]{2}{*}{ Canada } & \multirow{2}{*}{$\begin{array}{l}\text { Retrospective } \\
\text { cohort study }\end{array}$} & 45 (localised disease) & $24(53)$ & $22(49)$ & $6(13)$ & - \\
\hline & & & 17 (stage IV disease) & $8(47)$ & $9(53)$ & $5(29)$ & - \\
\hline Chou et al. [6] & Taiwan & $\begin{array}{l}\text { Retrospective } \\
\text { cohort study }\end{array}$ & 69 & $31(28.7)$ & $27(25.0)$ & $10(9.3)$ & $5(4.6)$ \\
\hline
\end{tabular}


Table 7 Management of CRC in AYAs

\begin{tabular}{|c|c|c|c|c|c|c|c|c|}
\hline Authors & Country & Study design & $\begin{array}{l}\text { Tumour types } \\
\text { (\% patients) }\end{array}$ & $\begin{array}{l}\text { No. of } \\
\text { patients }\end{array}$ & $\begin{array}{l}\text { TNM staging } \\
\text { (\% patients) }\end{array}$ & $\begin{array}{l}\text { Surgery } \\
\text { (\% patients, type) }\end{array}$ & $\begin{array}{l}\text { Chemotherapy } \\
\text { rates (\% patients) }\end{array}$ & $\begin{array}{l}\text { 5-year overall } \\
\text { survival } \\
\text { (\% patients) }\end{array}$ \\
\hline Kocian et al. [7] & $\begin{array}{l}\text { Czech } \\
\text { Republic }\end{array}$ & $\begin{array}{l}\text { Retrospective } \\
\text { study }\end{array}$ & 60 rectum, 40 colon & 38 & $\begin{array}{l}\text { I } 20 \\
\text { II, III and } \\
\text { IV- } 80\end{array}$ & $\begin{array}{c}82 \text { (curative }+ \\
\text { palliative) }\end{array}$ & 100 & 47.9 \\
\hline $\begin{array}{l}\text { Farraj } \\
\quad \text { et al. [25] }\end{array}$ & Lebanon & Case series & 52 rectum, 45 colon & 29 & - & - & 62 & - \\
\hline $\begin{array}{l}\text { Al-Barrak } \\
\text { et al. [16] }\end{array}$ & Canada & $\begin{array}{l}\text { Retrospective } \\
\text { study }\end{array}$ & 36 rectum, 64 colon & 78 & $\begin{array}{l}\text { I } 9 \\
\text { II } 42 \\
\text { III } 49\end{array}$ & $\begin{array}{l}76 \text { (primary } \\
\text { resection) }\end{array}$ & - & 12 \\
\hline $\begin{array}{l}\text { Kneuertz } \\
\quad \text { et al. [26] }\end{array}$ & USA & $\begin{array}{l}\text { Retrospective } \\
\text { study }\end{array}$ & $\begin{array}{l}\text { Relative to splenic } \\
\text { flexure: Distal } 56.3 \text {, } \\
\text { proximal } 39.9\end{array}$ & 13,102 & $\begin{array}{l}\text { I } 14.7 \\
\text { II } 23.5 \\
\text { III } 36.5 \\
\text { IV } 25.3\end{array}$ & 100 & $\begin{array}{l}66.8 \text { (single } \\
\text { agent } 15.6, \\
\text { multiple } \\
\text { agent 42.8, } \\
\text { unknown 7.8) }\end{array}$ & 61.7 \\
\hline $\begin{array}{l}\text { Chou } \\
\text { et al. [6] }\end{array}$ & Taiwan & $\begin{array}{l}\text { Retrospective } \\
\text { study }\end{array}$ & $\begin{array}{l}52.6 \text { rectosigmoid; } \\
47.7 \text { colon }\end{array}$ & 69 & $\begin{array}{l}\text { I } 8.7 \\
\text { II } 8.7 \\
\text { II } 40.6 \\
\text { IV } 42\end{array}$ & $\begin{array}{l}87 \text { (radical } \\
\text { resection) }\end{array}$ & 83 & 44.1 \\
\hline Zhao et al. [27] & China & $\begin{array}{l}\text { Retrospective } \\
\text { study }\end{array}$ & $\begin{array}{l}44.1 \text { rectum; } \\
55.9 \text { colon }\end{array}$ & 68 & $\begin{array}{l}\text { N/A } \\
\quad \text { (used AJCC) }\end{array}$ & 100 & 85.3 & 66.4 \\
\hline
\end{tabular}

systems already in place in primary care, implementation of earlier screening could be feasible.

The National Institute for Health and Care Excellence (NICE) guidelines do not report any specific recommendations for management of sporadic colorectal cancer in the young [32]. With regard to the management of young CRCs, we have very limited data on the types of resections performed and outcomes after chemotherapy to make robust recommendations. The National Bowel Cancer Audit (NBOCA) states that in the UK, patients who are younger with fewer comorbidities (ASA 1/2 and performance status 0/1) are more likely to receive chemotherapy [31]. In addition, younger patients are more likely to have long-course radiotherapy [31]. There is little evidence on the effectiveness of this aggressive management approach with guidelines for treatment based largely on older adults [5]. The better overall physical status of younger patients may mean that clinicians not only opt to treat this group more aggressively, but also that patients are more resilient to these treatment strategies. However, adopting an aggressive approach to treatment of AYAs, based on minimal research, may result in significant long-term effects and a poor quality of life with little survival benefit [26].

Following a review of the clinicopathologic characteristics presented, we hypothesise that CRCs in AYAs comprise a combination of a more aggressive and unique biological nature of tumour (Table 5). The genetic differences between age
Table 8 Summary of age-specific recommendations for the management of CRC in AYAs, from national and international guidelines

\begin{tabular}{ll}
\hline NCCN [30] & Management recommendations are made based on tumour stage and high-risk features \\
& - Overall benefit and toxicities of 5-FU/LVAS adjuvant therapy is similar in older and \\
& younger patients \\
- Advise consideration of more extensive colectomy for patients $<50$ years old & - Younger patients are more likely to receive chemotherapy \\
- Younger patients are more likely to have long-course radiotherapy & \\
NBOCA [31] & No specific recommendations for young patients $\leq 49$ years old \\
ESMO [33] & - No specific recommendations for young patients $\leq 49$ years old \\
ACS [34] & Regular screening at the age of 45 in people at average risk of CRC \\
& Patients at "average risk" should not have: a personal of family history of CRC, a \\
& personal history of IBD, a confirmed or suspected hereditary CRC syndrome, a \\
& personal history of radiotherapy to the abdomen or pelvis \\
& Testing options: stool based (FIT yearly or FOB yearly or MT-sDNA 3 yearly); \\
& structural examinations (colonoscopy 10 yearly or CTC 5 yearly or flexible \\
& sigmoidoscopy 5 yearly)
\end{tabular}

NCCN National Comprehensive Cancer Network, NBOCA National Bowel Cancer Audit, NICE National Institute for Health and Care Excellence, ESMO European Society of Medical Oncology, ACS American Cancer Society, FIT faecal immunochemical test, MT-sDNA multi-target stool DNA, CTC CT-colonography 
cohorts reveal the need for alternative treatment strategies and particular attention from oncology [19], specifically in the delivery of targeted therapy. The European Society for Medical Oncology (ESMO) guidelines recommend applying personalised medicine in the management of high-stage CRC [33]. Overall, further research is needed to target CRC in the young and develop specific treatment plans that reduce recurrence, increase overall survival and have the least detrimental long-term effect.

The majority of young adults with CRC across the included studies presented with rectal bleeding. The vague presentation of this disease requires increased awareness amongst clinicians, thus avoiding delayed diagnosis which may result in more advanced disease at presentation [35].

Research into biomarkers specific to sporadic CRC in the young is necessary to aid molecular subtyping of this disease entity, allowing earlier detection and personalised management. To further research, we suggest that a serum sample and all tumours from younger patients with CRC are sent for genetic testing [28]. This would promote expansion of the gene pool and perhaps allow collaborative research efforts into the pathological features of early onset sporadic CRCs.

\section{Limitations}

Our literature search was limited to studies published in English, which may have affected the inclusion of a number of potentially eligible studies from non-English speaking countries. The limited number and heterogeneity between studies meant that a systematic review was not feasible. Additionally, the variability between studies introduced challenges in presenting details of all study data.

\section{Conclusion}

Sporadic CRC in AYAs is a growing health concern that is underrepresented in clinical research [5]. Although recognised by national and international bodies, recommendations are limited by the sparsity of available data. In this scoping review, we have presented a comprehensive summary of available evidence based on five broad themes. The heterogeneity of the included studies presents challenges to making robust recommendations that can be incorporated into current guidelines. Given the rising incidence of this disease, we seek to highlight the need for further research aimed towards defining the role of earlier screening. Particularly, given its more aggressive histology, we seek to raise awareness and promote thorough assessment of young adults presenting with colonic and rectal symptoms.

Data availability All data is readily available.

\section{Compliance with ethical standards}

Conflict of interest The authors declare that they have no conflicts of interest.

Ethics approval Not applicable.

Consent to participate Not applicable.

Consent for publication All named authors have consented for paper submission and publication.

Code availability Not applicable.

Open Access This article is licensed under a Creative Commons Attribution 4.0 International License, which permits use, sharing, adaptation, distribution and reproduction in any medium or format, as long as you give appropriate credit to the original author(s) and the source, provide a link to the Creative Commons licence, and indicate if changes were made. The images or other third party material in this article are included in the article's Creative Commons licence, unless indicated otherwise in a credit line to the material. If material is not included in the article's Creative Commons licence and your intended use is not permitted by statutory regulation or exceeds the permitted use, you will need to obtain permission directly from the copyright holder. To view a copy of this licence, visit http://creativecommons.org/licenses/by/4.0/.

\section{References}

1. Cancer Research UK: Bowel cancer statistics. https://www. cancerresearchuk.org/health-professional/cancer-statistics/ statistics-by-cancer-type/bowel-cancer\#heading-One. (accessed $11 / 05 / 2020)$

2. Ferlay J et al (2019) Estimating the global cancer incidence and mortality in 2018: GLOBOCAN sources and methods. Int J Cancer 144(8):1941-1953. https://doi.org/10.1002/ijc.31937

3. Singh KE, Taylor TH, Pan CG, Stamos MJ, Zell JA (2014) Colorectal cancer incidence among young adults in California. $\mathrm{J}$ Adolesc Young Adult Oncol 3(4):176-184. https://doi.org/10. 1089/jayao.2014.0006

4. Davis DM, Marcet JE, Frattini JC, Prather AD, Mateka JJ, Nfonsam VN (2011) Is it time to lower the recommended screening age for colorectal cancer? J Am Coll Surg 213(3):352-361. https://doi.org/ 10.1016/j.jamcollsurg.2011.04.033

5. Levine O, Zbuk K (2019) Colorectal cancer in adolescents and young adults: defining a growing threat. Pediatr Blood Cancer 66(11):e27941. https://doi.org/10.1002/pbc.27941

6. Chou CL, Chang SC, Lin TC, Chen WS, Jiang JK, Wang HS, Yang SH, Liang WY, Lin JK (2011) Differences in clinicopathological characteristics of colorectal cancer between younger and elderly patients: an analysis of 322 patients from a single institution. Am J Surg 202(5):574-582. https://doi.org/10.1016/j.amjsurg.2010.10. 014

7. Kocian P, Whitley A, Blaha M, Hoch J (2017) Colorectal cancer in patients under the age of 40 years: experience from a tertiary care centre in the Czech Republic. Acta Chir Belg 117(6):356-362. https://doi.org/10.1080/00015458.2017.1321270

8. Venugopal A, Stoffel EM (2019) Colorectal cancer in young adults. Curr Treat Options Gastroenterol 17(1):89-98. https://doi.org/10. 1007/s11938-019-00219-4 
9. Arksey H, O'Malley L (2005) Scoping studies: towards a methodological framework. Int J Soc Res Methodol 8:19-32

10. Liberati A et al (2009) The PRISMA statement for reporting systematic reviews and meta-analyses of studies that evaluate health care interventions: explanation and elaboration. PLoS Med 6(7): e1000100. https://doi.org/10.1371/journal.pmed.1000100

11. Oxford Centre for Evidence-based Medicine - levels of evidence (March 2009). (accessed 21/04/2020, 2020)

12. Siegel RL et al (2017) Colorectal cancer incidence patterns in the United States, 1974-2013. J Natl Cancer Inst 109(8). https://doi. org/10.1093/jnci/djw322

13. Kwak JY, Kim KM, Yang HJ, Yu KJ, Lee JG, Jeong YO, Shim SG (2016) Prevalence of colorectal adenomas in asymptomatic young adults: a window to early intervention? Scand J Gastroenterol 51(6):731-738. https://doi.org/10.3109/00365521.2015.1130163

14. Chen KC, Chung CS, Hsu WF, Huang TY, Lin CK, Lee TH, Weng MT, Chiu CM, Chang LC, Chiu HM (2018) Identification of risk factors for neoplastic colonic polyps in young adults with bloody stool in comparison with those without symptom. J Gastroenterol Hepatol 33(7):1335-1340. https://doi.org/10.1111/jgh.14070

15. Kim NH, Jung YS, Yang HJ, Park SK, Park JH, Park DI, Sohn CI (2019) Prevalence of and risk factors for colorectal neoplasia in asymptomatic young adults (20-39 years old). Clin Gastroenterol Hepatol 17(1):115-122. https://doi.org/10.1016/j.cgh.2018.07.011

16. Al-Barrak J, Gill S (2011) Presentation and outcomes of patients aged 30 years and younger with colorectal cancer: a 20-year retrospective review. Med Oncol 28(4):1058-1061. https://doi.org/10. 1007/s12032-010-9639-4

17. Rosato V, Bosetti C, Levi F, Polesel J, Zucchetto A, Negri E, la Vecchia C (2013) Risk factors for young-onset colorectal cancer. Cancer Causes Control 24(2):335-341. https://doi.org/10.1007/ s10552-012-0119-3

18. Tawadros PS, Paquette IM, Hanly AM, Mellgren AF, Rothenberger DA, Madoff RD (2015) Adenocarcinoma of the rectum in patients under age 40 is increasing: impact of signet-ring cell histology. Dis Colon Rectum 58(5):474-478. https://doi.org/10.1097/DCR. 000000000000318

19. Weinberg BA, Marshall JL, Salem ME (2017) The growing challenge of young adults with colorectal cancer. Oncology 31(5):3819

20. Wanders LK et al (2020) IBD-associated dysplastic lesions show more chromosomal instability than sporadic adenomas. Inflamm Bowel Dis 26(2):167-180. https://doi.org/10.1093/ibd/izz171

21. Schellerer VS, Hohenberger W, Croner RS (2012) Is it time to lower the recommended screening age for colorectal cancer? J Am Coll Surg 214(3):377. https://doi.org/10.1016/j.jamcollsurg. 2011.12.004

22. Peterse EFP et al (2018) The impact of the rising colorectal cancer incidence in young adults on the optimal age to start screening: microsimulation analysis I to inform the American Cancer Society colorectal cancer screening guideline. Cancer 124(14):2964-2973. https://doi.org/10.1002/cncr.31543

23. Chang DT, Pai RK, Rybicki LA, Dimaio MA, Limaye M, Jayachandran P, Koong AC, Kunz PA, Fisher GA, Ford JM,
Welton M, Shelton A, Ma L, Arber DA, Pai RK (2012) Clinicopathologic and molecular features of sporadic early-onset colorectal adenocarcinoma: an adenocarcinoma with frequent signet ring cell differentiation, rectal and sigmoid involvement, and adverse morphologic features. Mod Pathol 25(8):1128-1139. https://doi.org/10.1038/modpathol.2012.61

24. Kothari N et al (2016) Increased incidence of FBXW7 and POLE proofreading domain mutations in young adult colorectal cancers. Cancer 22. https://doi.org/10.1002/cancer.30082

25. Farraj FA, Sabbagh H, Aridi T, Fakhruddin N, Farhat F (2019) Signet ring cell carcinoma of the colon in young adults: a case report and literature review. Case Rep Oncol Med 2019: 3092674-3092678. https://doi.org/10.1155/2019/3092674

26. Kneuertz PJ, Chang GJ, Hu CY, Rodriguez-Bigas MA, Eng C, Vilar E, Skibber JM, Feig BW, Cormier JN, You YN (2015) Overtreatment of young adults with colon cancer: more intense treatments with unmatched survival gains. JAMA Surg 150(5): 402-409. https://doi.org/10.1001/jamasurg.2014.3572

27. Zhao L, Bao F, Yan J, Liu H, Li T, Chen H, Li G (2017) Poor prognosis of young patients with colorectal cancer: a retrospective study. Int J Color Dis 32(8):1147-1156. https://doi.org/10.1007/ s00384-017-2809-5

28. Campos FG (2017) Colorectal cancer in young adults: a difficult challenge. World J Gastroenterol 23:5041-5044

29. Saad El Din K et al (2020) Trends in the epidemiology of youngonset colorectal cancer: a worldwide systematic review. BMC Cancer 20(1):288. https://doi.org/10.1186/s12885-020-06766-9

30. National Comprehensive Cancer Network (NCCN) Clinical Practice Guidelines in Oncology (NCCN Guidelines). https:// www.nccn.org/professionals/physician_gls/pdf/colon.pdf (accessed 26/4/2020, 2020)

31. National Bowel Cancer Audit Annual Report 2019. https://www. hqip.org.uk/resource/national-bowel-cancer-audit-annual-report2019/\#.XqV2hpNKj_Q (accessed 26/04/2020, 2020)

32. National Institute for Healthcare Excellence. https://www.nice.org. $\mathrm{uk} /$ guidance/conditions-and-diseases/cancer/colorectal-cancer/ products?Status=Published $($ accessed 08/05/2020)

33. European Society for Medical Oncology (ESMO) Clinical Practice Guidelines: Gastrointestinal Cancers. https://www.esmo.org/ Guidelines/Gastrointestinal-Cancers (accessed 10/05/2020)

34. American Cancer Society Guideline for Colorectal Cancer Screening https://www.cancer.org/cancer/colon-rectal-cancer/ detection-diagnosis-staging/acs-recommendations.html (accessed 10/05/2020, 2020)

35. Yong KK, Kyaw M, Chadwick G, Sundaram K (2020) Increasing incidence of young-onset colorectal cancers in the UK and rising mortality in rectal cancers. Gut. https://doi.org/10.1136/gutjnl2020-321069

Publisher's note Springer Nature remains neutral with regard to jurisdictional claims in published maps and institutional affiliations. 